\title{
Impact of Economic Integration and Information and Communication Technology on Economic Growth for European Union: Dynamic Panel GMM Approach
}

\author{
Muhammad Bilal Ahsin \\ Faculty of Economic and Business, Universiti Malaysia Sarawak \\ 94300 Kota Samarahan, Sarawak, Malaysia \\ Jerome Kueh (Corresponding author) \\ Faculty of Economic and Business, Universiti Malaysia Sarawak \\ 94300 Kota Samarahan, Sarawak, Malaysia \\ Tel: 60-825-8436 E-mail: kshjerome@unimas.my \\ Muhammad Asraf bin Abdullah \\ Faculty of Economic and Business, Universiti Malaysia Sarawak \\ 94300 Kota Samarahan, Sarawak, Malaysia
}

Received: July 29, 2021 Accepted: September 24, $2021 \quad$ Published: October 5, 2021

doi:10.5296/ber.v11i4.19064ＵRL: https://doi.org/10.5296/ber.v11i4.19064

\begin{abstract}
European Union is the strongest economic union globally and has observed rapid economic growth in the last few decades. This study investigates whether economic integration and information and communication technology (ICT) promotes economic growth in the EU. Additionally, the study examines the role of ICT for economic integration and growth relationship concerning ICT readiness and usage. The study undertook panel data from 2002 to 2019 and employed the Generalized Method of Moments approach to estimate results. The results revealed that economic integration and ICT enhance economic growth. Moreover, enhanced ICT stimulates the impact of economic integration on economic growth. The results also confirmed a more substantial effect of ICT usage on economic growth than ICT readiness.
\end{abstract}


Keywords: Economic integration, Information and communication technology, Economic growth, EU, GMM

\section{Introduction}

Economic growth enhancement is the principal objective of every economy that has been immensely contributed by economic integration. Theoretically, economic union or integration enhances productivity, capital accumulation and economic growth (Ehigiamusoe and Hooi, 2019). European Union (EU) is an economic, monetary and political union of 27 European countries establishment in 1957. Since its establishment, the next decade of the 1960s was quite significant with an economic growth perspective as custom duties on trade were eliminated for member countries. In 1986, the member countries signed the Single European Act, a vast program of six years. The primary purpose of this treaty was to create a "Single Market" by resolving issues related to the free flow of trade at EU borders. In 1993 EU completed single market and achieved "four freedoms". The "four freedoms" agenda includes free movement of money, goods, people and services across the EU. In the 1990s EU also signed two treaties, the Maastricht treaty and the treaty of Amsterdam. Maastricht treaty was signed in 1993, which renamed European Economic Community (EEC) to European Community to express the integration of region beyond economic matters. In 1999 Amsterdam treaty was signed through which some certain powers of the national government were transferred to the European parliament. In 2007, the Treaty of Lisbon was signed by the EU, which established centralized foreign policy, leadership and proper process for the country who wishfully applied to exit from the EU. Moreover, the EU has established many Free Trade Agreements (FTAs) with various countries worldwide including Georgia, Mexico, Moldova, South Korea, Colombia, Peru and Ukraine. Additionally, the EU has enhanced its economic integration with other countries by signing some additional trade agreements comprising of Association Agreements (AA), Custom Unions (CU), Economic Partnership Agreement (EPA) and European Economic Area (EEA). EU is the most potent economic union and the largest trading bloc in the world. EU's trade is $20 \%$ of global exports and imports, excluding intra EU trading activities (Chandan \& Nalin, 2018). Despite all these economic integration enhancements, EU member countries observed slow economic growth in the last couple of decades. The average annual GDP per capita growth rate of the EU from 1998 to 2007 was $2.29 \%$ but the average from 2008 to 2017 was significantly dropped down to $0.57 \%$ (WDI, 2019).

Information and Communications Technology (ICT) is inevitable for economic growth (Kuznets 1978). In the modern era of globalization, ICT has immensely reshaped the trade landscape leading to enhanced economic growth. However, this role is not a smooth process (Field 2006). History reveals that the transmission, innovation, or the collapse of the latest technologies accelerates or decelerates the economic growth abruptly. In particular, Information and Communication Technologies (ICT) transforms the firm's production processes, which ultimately transmute the country's overall production process and economic growth (Jalava and Pohjola, 2008). Therefore, this nexus needs empirical investigation.

Since 2007, ICT observed the emergence of novel innovations had increased the interest of 
numerous policymakers and researchers at EU. In 2010 European Union launched Digital Agenda (DA) across Europe to contribute significantly towards the economic growth of the EU and extend the benefits of the digital era to every part of society. The EU's digital agenda focuses on developing infrastructure for enhanced access towards fast internet connections, innovation in ICR, knowledge development, and implementing intelligent use of ICT across all parts of society, i.e., health, energy, etc. The DA of EU has inspired local authorities, regions and national governments to develop digital agendas at their respective political levels to ensure priorities on policy settings and taking ICT initiatives (European Commission 2015). However, in the EU, various countries are at different levels of digital adoption.

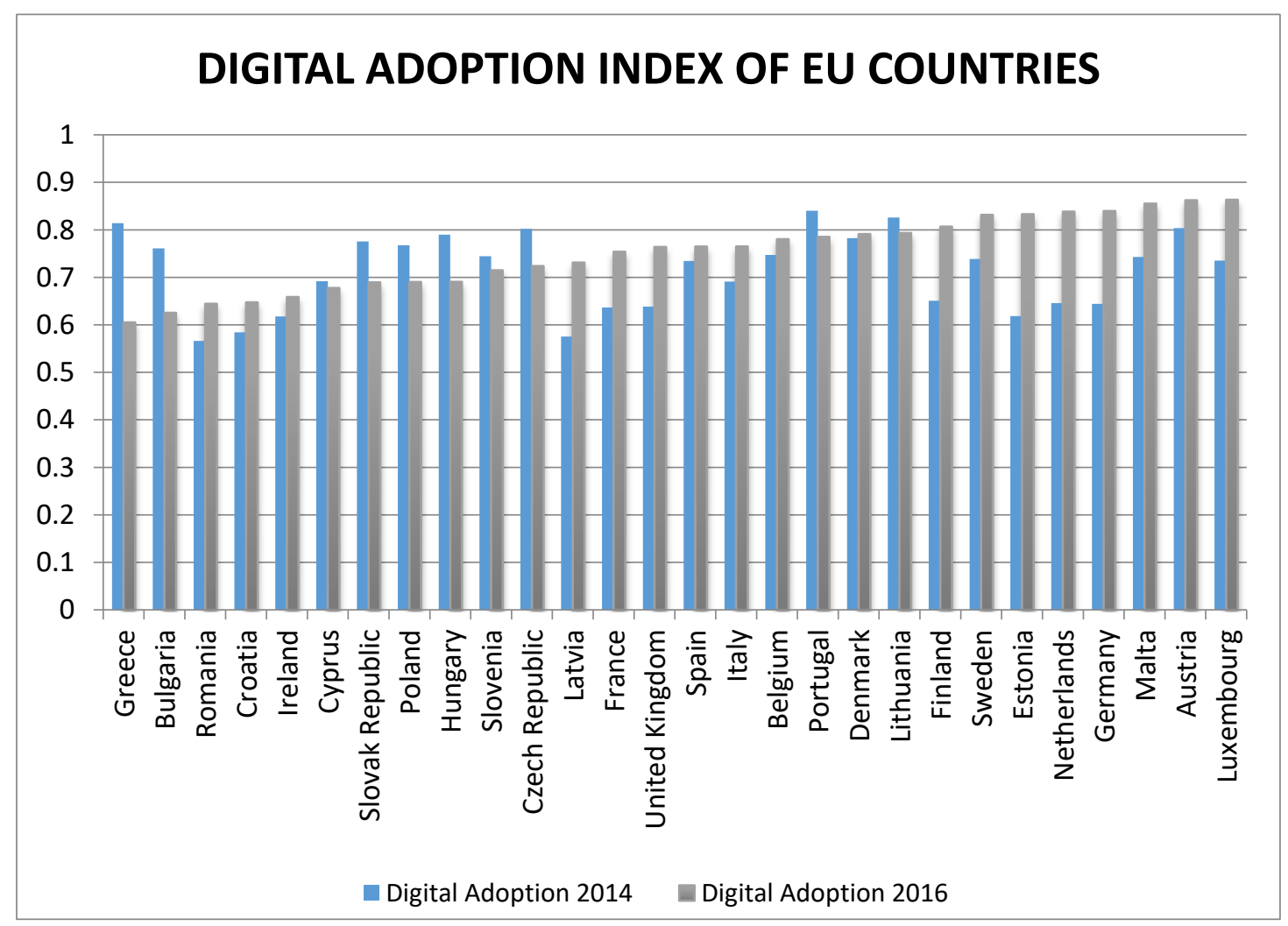

Figure 1. Digital Adoption Index of EU Countries

Source: World Development Indicators (2019)

Figure 1 shows Digital Adoption for EU countries on a scale of 0-1. EU countries are enhancing digital technology adoption as Figure 1 clearly illustrates that overall digital adoption increased in 2016 for most countries compared to 2014. It is also notable different EU countries have a different level of digital adoption, indicating a digital divide in the EU that can cause carb economic growth. Wyatt et al. (2005) defined digital as the overarching conception to capture unequal access to ICT at global and local levels. So, the phenomenon digital divide is based on access to ICT where access of ICT is grounded on ICT readiness. In the nutshell, the existence of the digital divide creates significance regarding the role of ICT for economic integration and growth nexus specifically with respect to ICT usage and readiness. 


\section{Literature Review}

The theoretical basis of this study is established on endogenous growth model and new trade theory. Various past studies have used endogenous growth models and new trade theory as theoretical framework to investigate the economic integration and growth nexus (Tumwebaze \& Ijjo, 2015; Bong \& Premaratne, 2018). Bong and Premaratne (2018) conducted a panel data analysis on ASEAN region to investigate the impact of economic integration on growth by considering endogenous growth model. The authors took data of 43 years ranging from 1970 to 2013 and reported a significant positive impact of regional economic integration on economic growth. Similarly, Tumwebaze and Ijjo (2015) considered the new trade theory to investigate the impact of economic integration on growth. The authors concluded that economic integration significantly contributed to GDP growth in COMESA.

Balassa (1961) carried out the first key systematic descriptive study based on economic integration. Since then, various studies have shown different results for economic integration and growth relationship. Landau (1995) conducted a study on 17 OECD countries from 1950 to 1990 and reported that economic growth observed no impacts from integration. Another study conducted by Brada and Mendez (1988) used Pooled data set of EU countries revealed that investment affects growth in the region. However, OLS estimation suggested that integration has no impact on economic growth. Similarly, Badinger (2005) built a different construct that changed from EU membership to account for economic integration. He constructed a dynamic process to measure EU integration that considers complex global tendencies and includes the impact of various speeds of integration. The researcher used panel data for fifteen EU member states from 1950 to 2000. However, he claimed that economic integration had no permanent effects on economic growth but confirmed the level effects of EU's integration. The author concluded that the GDP of the EU would be 20 percent less in the absence of EU economic integration.

On the contrary, many studies revealed a positive and significant impact of EU integration on economic growth. Italianer (1994) organized a study to investigate the impacts of regional integration on economic growth by selecting six EU countries for 1961-1992. He used integration measuring variables based on trade flows for the estimation of results. The author reported significant growth effects of general levels of openness and regional economic integration. Henrekson et al. (1997) confirmed that European integration has a significant and permanent impact ranging from 0.60 to 1.30 percent per annum on the growth of the EU that was rejected by Vanhoudt (1999). Moreover, Fetahi-Vehapi et al. (2015) also conducted a study on ten southeast European countries examining the impact of trade openness and growth. They reported that trade openness affects economic growth positively in Europe. Although the impact of European integration on economic growth remains inconclusive due to methodological difficulties but significant heterogeneity is also observed across countries Campos (2018), which is a severe concern for growth (Crespo et al., 2008).

Information and Communication Technology (ICT) has also contributed to economic growth (Dewan, 2000; Cardona, Kretschmer, \& Strobel, 2013; Ishida, 2015). Gruber et al. (2014) conducted empirical analysis for 27 EU countries by using panel data from 2005-2011 and 
reported that broadband adoption has a positive and significant effect on economic growth. On the other hand, many studies investigated the impact of ICT on economic growth for EU member countries that showed contradictory results (Kraemer \& Dedrick, 2001; Jalava \& Pohjola, 2007; Vijselaar \& Albers, 2004; Timmer et al., 2007; Venturini, 2009). Moreover, many theoretical and empirical studies on economic integration and growth nexus also revealed mixed results (Harrison, 1996; Yanikkaya, 2003; Dowrick \& Golley, 2004; Rassekh, 2007). So, the digital divide in the EU and contradictory outcomes of economic integration and growth nexus, it is essential to explore the impact of economic integration and ICT on economic growth and the role of ICT for economic integration and growth nexus.

\section{Data and Methodology}

The study undertakes a panel dataset of 27 EU countries ranging from the year 2002 to 2019. The annual data is obtained from various data sources, including World Bank, International Telecommunications Union (ITU) and Penn World Table (PWT) version 9.1. The observations are constructed as non-overlapping average of three years that provides six periods for $27 \mathrm{EU}$ countries. The three-year average is constructed to mitigate business cycle fluctuations and capture the actual effect of economic integration on growth in long- and medium-term variations instead of short-term variations. More particularly, the non-overlapping average assists in drawing results to be less subjective to the permanent and temporary shocks. Ehigiamusoe and Lean (2019) also suggested that many previous studies on economic integration used non-overlapping average data.

New Trade Theory and Endogenous Growth Model serve as theoretical support for this study. New Trade Theory states that increase in trade or enhanced economic integration upsurges economic growth. Moreover, Endogenous Growth Model postulates that determinants of economic growth are explained inside the model. AK model is a form of endogenous growth model that is based on physical capital accumulation. The model uses a basic production function

$$
Y=A K
$$

Where, $Y$ shows the level of production, $A$ denotes technology and $K$ shows capital accumulation. This study extends above mentioned AK model by adding economic integration as duly supported by New Trade Theory. The study also examines the impact of ICT on economic growth. Further, the study also adopts human capital, employment rate and inflation as control variables (Chimobi 2010; Paparas, Richter, \& Paparas, 2015; Ahmed \& Ahmad, 2016 and Murphy, \& O’Reilly, 2019).

The analysis of the study consists of descriptive statistics, correlation analysis and Dynamic Panel regression Generalized Method of Moments (Hansen, 1982). Generalized Method of Moments (GMM) considers the instrumental variable approach to estimate the results. Since the best fit instrumental variable is usually unknown, the lagged dependent variable is used as an an instrumental variable to infer results. These instrumental variables of the dynamic GMM estimators follow moment conditions and are used for short panels where the 


\section{Macrothink}

cross-sections are more than the time intervals (Arellano \& Bond, 1991; Arellano \& Bover, 1995; Blundell \& Bond, 1998). GMM is also used to rule out the problems of serial correlation and endogeneity. Further, to check the veracity of the results, the post-analysis tests of Sargran and Arellano Bond are used to check the validity of the instruments and serial correlation, respectively. Considering the GMM model, Equation (1) can be rewritten as:

$$
\operatorname{lnEG}_{\mathrm{it}}=\beta_{0}+\beta_{1} \operatorname{lnEG} \mathrm{it-1}+\beta_{2} \operatorname{lnEI} i \mathrm{t}+\beta_{3} \operatorname{lnICT}_{i t}+\beta_{4} \operatorname{lnHC}_{i t}+\beta_{5} \operatorname{lnEMP}_{i t}+\beta_{6} \operatorname{lnINF}_{i t}+\varepsilon_{\mathrm{it}}
$$

Where $t$ shows time period for each $i$ country. Further, in Equation $2 E G, E I, I C T, H C, E M P$ INF and $\varepsilon$ denotes Economic Growth, Economic, ICT, Human Capital, Employment Rate, Inflation Rate and disturbance term, respectively. Betas denote coefficients and In natural indicates logarithm in the equation for all variables to standardize the dataset. The scope of the study is not limited to the impact of economic integration and ICT on economic growth. Still, it will also explore the role of ICT for economic integration and growth relationship. So, Equation (2) can be rewritten as

$$
\begin{gathered}
\operatorname{lnEG} G_{i t}=\beta_{0}+\beta_{1} \operatorname{lnEG}_{\mathrm{it}-1}+\beta_{2} \operatorname{lnEI}_{i \mathrm{t}}+\beta_{3} \operatorname{lnICT}_{i t}+\beta_{4} \operatorname{lnICT}_{i t} * \operatorname{lnEI}_{i \mathrm{t}}+\beta_{5} \operatorname{lnHC}_{i t}+\beta_{6} \\
\operatorname{lnEMP}_{i t}+\beta_{7} \operatorname{lnINF}_{i t}+\varepsilon_{\mathrm{it}}
\end{gathered}
$$

The study considers ICT concerning readiness and usage. Therefore, regression analysis will be based on four models as the models presented in Equation 2 and Equation 3 will be examined concerning ICT readiness and usage. 
Table 1. Data and Measurements

\begin{tabular}{|c|c|c|c|c|}
\hline Variables & Definition & Proxy & Reference & Data Source \\
\hline $\begin{array}{l}\text { Economic } \\
\text { Growth (EG) }\end{array}$ & $\begin{array}{l}\text { Hussin and Saidin } \\
(2012) \text { mentioned that } \\
\text { economic growth is the } \\
\text { measure of aggregate } \\
\text { proliferation in the } \\
\text { economic sectors of a } \\
\text { country }\end{array}$ & $\begin{array}{l}\text { Gross } \\
\text { Domestic } \\
\text { Product Per } \\
\text { Capita (GDP } \\
\text { per capita is a } \\
\text { better measure } \\
\text { for economic } \\
\text { growth as it } \\
\text { considers the } \\
\text { change in } \\
\text { population.) }\end{array}$ & $\begin{array}{l}\text { (Makki \& Somwaru, } \\
\text { 2004; Iyidoğan et } \\
\text { al., 2017; Bong \& } \\
\text { Premaratne, } 2018 \\
\text { and Latif et al., } \\
\text { 2018). }\end{array}$ & World Bank \\
\hline $\begin{array}{l}\text { Economic } \\
\text { Integration (EI) }\end{array}$ & $\begin{array}{l}\text { Machlup (1977) defined } \\
\text { economic integration as } \\
\text { the process through } \\
\text { which different } \\
\text { economies form a larger } \\
\text { economic region }\end{array}$ & $\begin{array}{l}\text { Total Trade as } \\
\text { a percentage of } \\
\text { GDP }\end{array}$ & $\begin{array}{l}\text { (Grubert \& Mutti, } \\
\text { 2000; Devereux, } \\
\text { Griffith \& Klemm, } \\
\text { 2002; Loretz, 2007 } \\
\text { and Bong \& } \\
\text { Premaratne, 2018) } \\
\end{array}$ & World Bank \\
\hline \multirow[t]{2}{*}{$\begin{array}{l}\text { Information and } \\
\text { Communication } \\
\text { Technology } \\
\text { (ICT) }\end{array}$} & \multirow[t]{2}{*}{$\begin{array}{l}\text { Yusuf (2005) described } \\
\text { ICT as the diversified } \\
\text { application } \\
\text { computing, } \\
\text { telecommunication, } \\
\text { communication and } \\
\text { satellite technology }\end{array}$} & $\begin{array}{l}\text { ICT Usage: } \\
\text { Internet users } \\
\text { per hundred } \\
\text { populations } \\
\text { (IU) }\end{array}$ & $\begin{array}{l}\text { (Roller } \& \\
\text { Waverman, } 2001 \\
\text { and Raheem, Tiwari, } \\
\& \\
\text { Balsalobre-lorente, } \\
2019)\end{array}$ & $\begin{array}{l}\text { World Bank and } \\
\text { International } \\
\text { Telecommunications } \\
\text { Union (ITU) }\end{array}$ \\
\hline & & $\begin{array}{l}\text { ICT Readiness: } \\
\text { Mobile Phone } \\
\text { Subscription } \\
\text { (MS) }\end{array}$ & $\begin{array}{l}\text { (Kumar \& Kumar, } \\
2019 \text { and Maiti \& } \\
\text { Awasthi, 2019) }\end{array}$ & \\
\hline $\begin{array}{l}\text { Human Capital } \\
\text { (HC) }\end{array}$ & $\begin{array}{l}\text { Human capital can be } \\
\text { defined as "the } \\
\text { knowledge and skills } \\
\text { that make a person } \\
\text { productive" or as the } \\
\text { "personal stock of } \\
\text { knowledge, know-how, } \\
\text { and skills that enables a } \\
\text { person to be productive } \\
\text { and thus earn income" } \\
\text { (McConnell, Brue, and } \\
\text { Flynn, p. 509, 283). }\end{array}$ & $\begin{array}{l}\text { Human capital } \\
\text { index based on } \\
\text { years } \\
\text { schooling and } \\
\text { returns } \\
\text { education }\end{array}$ & $\begin{array}{l}\text { (Ahmed \& Ahmad, } \\
2016 \text { and Murphy, \& } \\
\text { O'Reilly, 2019) }\end{array}$ & $\begin{array}{l}\text { Penn } \text { World Table } \\
\text { (PWT) version } 9.1\end{array}$ \\
\hline $\begin{array}{l}\text { Employment } \\
\text { Rate (EMP) }\end{array}$ & $\begin{array}{l}\text { Employment rate can be } \\
\text { defined as the percentage } \\
\text { of the labor force which } \\
\text { is employed Hossine } \\
\text { Sharif, S. (2016). }\end{array}$ & $\begin{array}{l}\text { No. of Persons } \\
\text { Engaged per } \\
\text { million }\end{array}$ & $\begin{array}{l}\text { (Baksa \& Kónya, } \\
\text { 2019) }\end{array}$ & $\begin{array}{l}\text { Penn World Table } \\
(\text { PWT) version } 9.1\end{array}$ \\
\hline Inflation (INF) & $\begin{array}{l}\text { Reilly, Johnson, and } \\
\text { Smith (1970) defined } \\
\text { inflation as a rise in the } \\
\text { general price level of a } \\
\text { country. }\end{array}$ & $\begin{array}{l}\text { Consumer } \\
\text { Price Index }\end{array}$ & $\begin{array}{l}\text { Bruno and Easterly } \\
(1995) ; \quad \text { Chimobi } \\
(2010) ; \text { Ahmed and } \\
\text { Mortaza (2005); } \\
\text { Saeed (2007) }\end{array}$ & World Bank \\
\hline
\end{tabular}

*, ** Internet usage and mobile phone subscription have been considered as proxies for ICT usage and readiness respectively, due to data availability 


\section{Results and Discussion:}

This section consists of descriptive statistics of the data, correlation and dynamic panel GMM regression analysis, and diagnostic tests.

Table 2. Descriptive Statistics

\begin{tabular}{|c|c|c|c|c|c|c|}
\hline Variable & & Mean & Std. Dev. & Min & Max & Observations \\
\hline \multirow[t]{3}{*}{ InEG } & overall & 4.5860 & 0.5794 & 3.6257 & 6.6434 & $\mathrm{~N}=162$ \\
\hline & between & & 0.5789 & 3.9669 & 6.4567 & $\mathrm{n}=27$ \\
\hline & within & & 0.1046 & 4.1584 & 4.8907 & $\mathrm{~T}=6$ \\
\hline \multirow[t]{3}{*}{$\operatorname{lnEI}$} & overall & 2.0321 & 0.2023 & 1.6740 & 2.5990 & $\mathrm{~N}=162$ \\
\hline & between & & 0.1990 & 1.7271 & 2.5243 & $\mathrm{n}=27$ \\
\hline & within & & 0.0505 & 1.8987 & 2.1297 & $\mathrm{~T}=6$ \\
\hline \multirow[t]{3}{*}{$\operatorname{lnIU}$} & overall & 1.7811 & 0.1783 & 1.0068 & 1.9901 & $\mathrm{~N}=162$ \\
\hline & between & & 0.1074 & 1.5349 & 1.9461 & $\mathrm{n}=27$ \\
\hline & within & & 0.1436 & 1.2530 & 2.0872 & $\mathrm{~T}=6$ \\
\hline \multirow[t]{3}{*}{$\operatorname{lnMS}$} & overall & 6.9030 & 0.5990 & 5.4638 & 8.0413 & $\mathrm{~N}=162$ \\
\hline & between & & 0.6012 & 5.6484 & 7.9611 & $\mathrm{n}=27$ \\
\hline & within & & 0.0927 & 6.5133 & 7.0458 & $\mathrm{~T}=6$ \\
\hline \multirow[t]{3}{*}{$\operatorname{lnEI} * \ln I U$} & overall & 3.6308 & 0.5783 & 1.7667 & 5.1567 & $\mathrm{~N}=162$ \\
\hline & between & & 0.4596 & 2.8626 & 4.8312 & $\mathrm{n}=27$ \\
\hline & within & & 0.3602 & 2.5215 & 4.3305 & $\mathrm{~T}=6$ \\
\hline \multirow{3}{*}{$\operatorname{lnEI} * \operatorname{lnMS}$} & overall & 14.008 & 1.7085 & 10.176 & 18.6203 & $\mathrm{~N}=162$ \\
\hline & between & & 1.6624 & 10.913 & 17.8898 & $\mathrm{n}=27$ \\
\hline & within & & 0.4909 & 12.6914 & 14.7728 & $\mathrm{~T}=6$ \\
\hline \multirow[t]{3}{*}{ InEMP } & overall & 6.5011 & 0.5838 & 5.1698 & 7.6532 & $\mathrm{~N}=162$ \\
\hline & between & & 0.5914 & 5.2411 & 7.6193 & $\mathrm{n}=27$ \\
\hline & within & & 0.0436 & 6.1504 & 6.6462 & $\mathrm{~T}=6$ \\
\hline \multirow[t]{3}{*}{$\operatorname{lnHC}$} & overall & 0.50074 & 0.0425 & 0.3494 & 0.5822 & $\mathrm{~N}=162$ \\
\hline & between & & 0.0406 & 0.3725 & 0.5613 & $\mathrm{n}=27$ \\
\hline & within & & 0.0143 & 0.4614 & 0.5448 & $\mathrm{~T}=6$ \\
\hline \multirow[t]{3}{*}{$\operatorname{lnINF}$} & overall & 2.2705 & 2.0033 & -1.6270 & 16.5667 & $\mathrm{~N}=162$ \\
\hline & between & & 1.0641 & 1.3806 & 6.1922 & $\mathrm{n}=27$ \\
\hline & within & & 1.7077 & -4.2783 & 12.6450 & $\mathrm{~T}=6$ \\
\hline
\end{tabular}

Source: The authors

Table 2 indicates the data's descriptive statistics, including mean, standard deviation, total number of observations, number of cross sections, number of years, and minimum and maximum values. The total number of observations, number of cross-sections and number of the year groups are 162, 27 and 6, respectively. To standardize all the variables, natural logarithm is taken for all the variables denoted by "ln". Economic Growth values range between 3.63 to 6.64 with mean of 4.59 and standard deviation of 0.58 indicating different economic growth in the the EU (Putranti, 2016). Similarly, the value of Economic Integration ranges between 1.67 to 2.60 , with a mean of 2.03 and a standard deviation of 0.20 showing mild heterogeneity. Similarly, Inflation and Employment Rate have a slightly high standard deviation of 2.00, 0.58 respectively. Moreover, Mobile Phone Subscription and its interaction with Economic Integration have a higher standard deviation of 0.59 and 1.70, respectively, indicating the digital divide in the EU (Negreiro, 2015). 


\section{Macrothink}

Business and Economic Research

ISSN 2162-4860

2021, Vol. 11, No. 4

Table 3. Correlation Analysis

\begin{tabular}{|c|c|c|c|c|c|c|c|c|c|}
\hline & InEG & InEI & $\operatorname{lnIU}$ & $\operatorname{lnMS}$ & $\operatorname{lnEI} * \ln I \mathrm{U}$ & InEI*InMS & InEMP & $\operatorname{lnHC}$ & InINF \\
\hline $\operatorname{lnEG}$ & 1.0000 & - & - & - & - & - & - & - & - \\
\hline $\operatorname{lnEI}$ & 0.6783 & 1.0000 & - & - & - & - & - & - & - \\
\hline $\operatorname{lnIU}$ & 0.1995 & 0.3148 & 1.0000 & - & - & - & - & - & - \\
\hline $\operatorname{lnMS}$ & 0.2152 & -0.1644 & 0.1655 & 1.0000 & - & - & - & - & - \\
\hline $\operatorname{lnEI}{ }^{*} \operatorname{lnIU}$ & 0.1632 & 0.6216 & 0.6969 & -0.0150 & 1.0000 & - & - & - & - \\
\hline $\operatorname{lnEI}{ }^{*} \ln M S$ & 0.2538 & 0.6849 & 0.3568 & 0.6010 & 0.6392 & 1.0000 & - & - & - \\
\hline InEMP & 0.0378 & -0.6845 & -0.0230 & 0.2190 & -0.4413 & $\begin{array}{l}-0.3968 \\
\end{array}$ & 1.0000 & - & - \\
\hline $\operatorname{lnHC}$ & 0.2131 & 0.1457 & 0.4551 & 0.3037 & 0.3559 & 0.3212 & -0.0420 & 1.0000 & - \\
\hline InINF & -0.2212 & -0.0817 & -0.5253 & -0.1726 & -0.3594 & -0.1854 & -0.0465 & -0.4423 & 1.0000 \\
\hline
\end{tabular}

Source: The authors

Table 3 depicts correlation analysis where all the variables were put into the bivariate correlation analysis to note their co-movements and the multicollinearity issues were also analyzed by the correlations coefficients. Notably, economic integration has a strong association with economic growth, whereas variables of ICT and their respective interactions have a weak correlation with economic growth. On the other hand, all independent and control variables, including interaction terms, have an association of less than 0.70 , indicating that data is not impeded with multicollinearity (Lind, Marchal \& Wathen, 2012; Vatcheva, Lee, McCormick \& Rahbar, 2016). 
Table 4. Dynamic Panel GMM Regression Analysis

\begin{tabular}{|l|l|l|l|l|}
\hline & $(\mathbf{1})$ & $(\mathbf{2})$ & $\mathbf{( 3 )}$ & $\mathbf{( 4 )}$ \\
\hline & $\mathbf{l n E G}$ & $\mathbf{l n E G}$ & $\mathbf{l n E G}$ & $\mathbf{l n E G}$ \\
\hline & $\mathbf{b} / \mathbf{t}$ & $\mathbf{b} / \mathbf{t}$ & $\mathbf{b} / \mathbf{t}$ & $\mathbf{b} / \mathbf{t}$ \\
\hline L1.InEG & $0.41977^{* * *}$ & $0.29058^{* * *}$ & $0.24182^{* * *}$ & $0.55643^{* * *}$ \\
\hline & $(7.1)$ & $(2.8)$ & $(2.8)$ & $(14.0)$ \\
\hline InEI & $0.36907^{* * *}$ & $3.82505^{* * *}$ & $0.22944^{* *}$ & $0.38469^{*}$ \\
\hline & $(3.4)$ & $(2.7)$ & $(2.5)$ & $(1.8)$ \\
\hline InEMP & $1.30485^{* * *}$ & $1.32176^{* * *}$ & $1.33134 * * *$ & $0.77859^{* * *}$ \\
\hline & $(5.9)$ & $(5.5)$ & $(8.9)$ & $(15.1)$ \\
\hline InHC & 0.20200 & 0.46225 & $2.65138^{* * *}$ & $1.03709^{* *}$ \\
\hline & $(0.2)$ & $(0.4)$ & $(3.1)$ & $(2.5)$ \\
\hline InINF & 0.00037 & -0.00078 & 0.00058 & $-0.00123^{* *}$ \\
\hline & $(0.4)$ & $(-0.8)$ & $(0.6)$ & $(-2.5)$ \\
\hline InIU & $0.16262^{* *}$ & $-4.14710^{* * *}$ & - & - \\
\hline & $(2.2)$ & $(-2.8)$ & & \\
\hline InEI * InIU & - & $2.15698^{* * *}$ & - & - \\
\hline & & $(2.9)$ & & \\
\hline InMS & - & - & $0.12029 *$ & $-0.25809^{* * *}$ \\
\hline & & & $(1.8)$ & $(-3.4)$ \\
\hline InEI * InMS & - & - & - & $0.07259^{* *}$ \\
\hline & & & & $(2.1)$ \\
\hline Observations & 138 & 138 & 138 & 138 \\
\hline No. of Groups & 27 & 27 & 27 & 27 \\
\hline No. of Instruments & 18 & 18 & 19 & 21 \\
\hline AR1 & 0.056 & 0.049 & 0.049 & 0.146 \\
\hline AR 2 & 0.388 & 0.103 & 0.697 & 0.090 \\
\hline Hansen & 0.097 & 0.807 & 0.569 & 0.110 \\
\hline Sargan & 0.337 & 0.666 & 0.595 & 0.122 \\
\hline
\end{tabular}

Source: The authors.

Notes: The t-statistics are in parentheses. *,** and *** indicate statistically significant at $10 \%, 5 \%$ and $1 \%$ level, respectively.

The GMM results are computed by using xtabond2 command robust standard errors in STATA 16.

Table 4 shows Two-Step Difference GMM regression analysis and diagnostic tests, including the Arnello Bond test, Hansen and Sargan test. The regression analysis consists of four models where economic growth is the dependent variable and the first lag of economic growth, economic integration, human capital, employment rate and inflation are taken as regressors. Internet Users and Mobile Phone Subscribers are taken as regressors with ICT usage and readiness in model one and model three, respectively. Further, in models two and four, Internet Users and Mobile Phone Subscribers are used as regressors with economic integration interaction.

In all four models, the first lag of economic growth impacts positively on economic growth. The coefficients are $0.41977,0.29058,0.24182$ and 0.55643 for models one, two, three and four, respectively. All coefficients are significant at $1 \%$ that confirms the dynamic impact of economic growth in all four models (Bong \& Premaratne, 2018). Similarly, Economic Integration also impacts positively and significantly on economic growth in all four models. The results of economic integration and growth nexus are also consistent with previous 
studies (Kien, 2009; Sharma \& Chua 2000; Vogiatzoglou \& Nguyen, 2016 and Bong \& Premaratne, 2018). In the same way, the Employment rate has a positive and significant impact on economic growth as all the coefficients are significant at $1 \%$ in all four models (Ahmad \& Ahmed, 2016). Further, the human capital has a positive and insignificant impact on economic growth in the first two models but the results are significant in the last two models (Barro, 1991; Hanushek \& Kimko, 2000; Greenway et al., 2002; Ndambiri et al., 2012; Bong \& Premaratne, 2018). On the other hand, the impact of inflation is insignificant on economic growth in all models except model four where inflation has negative and significant impact on economic growth (Barro, 1995; Bruno \& Easterly, 1998; Vaona \& Schiavo, 2007; Vaon, 2012).

The results reveal the positive and significant impact of ICT on economic growth (Dimelis \& Papaioannou, 2010; Vu, 2011; Ahmed \& Ridzuan. 2013 and Sassi \& Goaied 2013), where the magnitude and significance of mobile phone subscribers are more minor than internet users. Model two and four show the moderating role of ICT for economic integration and growth nexus. The interaction terms of internet users and economic integration in model two and mobile phone subscribers and economic integration in model four show that increased internet users and mobile phone subscriptions strengthen economic integration and growth relationship. On the other hand, the magnitude of internet users is more significant than mobile phone subscriptions. Table 4 also shows diagnostic tests for GMM regression, including Hansen and Sargan over-identification of instruments and Arnello Bond Serial Correlation test. For all four models, the number of instruments is less than the number of cross-sections. Moreover, the instruments are not over identified as p values for Sargan and Hansen tests are more than 0.05 . Further, there is no serial correlation as the p-value of AR 2 is more than 0.05 for all four models.

\section{Conclusion}

This study investigates the impact of economic integration on economic growth and explores the role of ICT for economic integration and growth relationship. Additionally, human capital, inflation and employment rate are taken as control variables for the study. The results revealed that economic integration and ICT both have a significant and positive impact on economic growth. The results revealed that economic integration and ICT both have a significant and positive impact on economic growth in EU, that is in line with the postulations of both endogenous growth model and new trade theory. Furthermore, the impact of ICT usage or internet users on economic growth is more potent than ICT readiness or mobile phone subscription. Moreover, the employment rate and human capital have a positive and significant impact on economic growth, whereas inflation's impact is negative on economic growth. Further, results also indicated that enhanced internet usage and mobile phone subscription would strengthen economic integration and growth nexus. More specifically, the role of internet users is more dexterous for economic integration and growth relationship. Conclusively, Economic integration could serve as an essential factor for economic growth in EU region. Public institutions should highly consider implementing policies that can enhance economic integration to promote economic growth in EU countries. More specifically, our empirical results suggest that ICT usage and readiness are also 
imperative to improve economic growth in EU member countries. Further policymakers should focus more on enhancing the number of internet users or ICT usage in the EU while planning for the Digital Agenda of the EU as it plays a more significant and positive role in economic integration and growth nexus. However, the study has not discussed any level or precise thresholds for ICT specifically with respect to ICT readiness and usage. Therefore, further research could be considered to determine to what extent the impact of ICT is significant for economic integration and growth nexus in the EU region.

\section{Acknowledgement}

Financial support from Universiti Malaysia Sarawak (UNIMAS) - PGRG Postgraduate Student Research: 8847 , is gratefully acknowledged.

\section{References}

Ahmed, E. M., \& Ridzuan, R. (2013). The impact of ICT on East Asian economic growth: panel estimation approach. Journal of the Knowledge Economy, 4(4), 540-555.

https://doi.org/10.1007/s13132-012-0096-5

Ahmed, R. N., \& Ahmad, K. (2016). Impact of population on economic growth: A case study of Pakistan. Bulletin of Business and Economics (BBE), 5(3), 162-176.

Ahmed, S., \& Mortaza, M. G. (2010). Inflation and economic growth in Bangladesh: 1981-2005 (No. id: 3033).

Arellano, M., \& Bond, S. (1991). Some tests of specification for panel data: Monte Carlo evidence and an application to employment equations. The review of economic studies, 58(2), 277-297. https://doi.org/10.2307/2297968

Arellano, M., \& Bover, O. (1995). Another look at the instrumental variable estimation of error-components models. Journal of econometrics, 68(1), 29-51.

https://doi.org/10.1016/0304-4076(94)01642-D

Badinger, H. (2005). Growth effects of economic integration: evidence from the EU member states. Review of World Economics, 141(1), 50-78.

https://doi.org/10.1007/s10290-005-0015-y

Baksa, D., \& Kónya, I. (2019). Convergence, productivity and debt: the case of Hungary (No. MT-DP-2019/16). IEHAS Discussion Papers.

Balassa, B. (1961). The Theory of Economic Integration. Homewood, Illinois: Richard D. Irwin. https://doi.org/10.1111/j.1467-6435.1961.tb02365.x

Barro, R. J. (1995). Inflation and Economic Growth. Cambride, MA, NBER. https://doi.org/10.3386/w5326

Blundell, R., \& Bond, S. (1998). Initial conditions and moment restrictions in dynamic panel data models. Journal of econometrics, 87(1), 115-143.

https://doi.org/10.1016/S0304-4076(98)00009-8 


\section{Al Macrothink}

Business and Economic Research ISSN 2162-4860 2021, Vol. 11, No. 4

Bong, A., \& Premaratne, G. (2018). Regional integration and economic growth in Southeast Asia. Global Business Review, 19(6), 1403-1415. https://doi.org/10.1177/0972150918794568

Brada, J. C., \& Mendez, J. A. (1988). An estimate of the dynamic effects of economic integration. The Review of Economics and Statistics, 163-168. https://doi.org/10.2307/1928166

Bruno, M., \& Easterly, W. (1995). Inflation and long-run growth. NBER Working Paper Series, 5209. https://doi.org/10.3386/w5209

Campos, N. F., Coricelli, F., \& Moretti, L. (2019). Institutional integration and economic growth in Europe. Journal of Monetary Economics, 103, 88-104.

https://doi.org/10.1016/j.jmoneco.2018.08.001

Cardona, M., Kretschmer, T., \& Strobel, T. (2013). ICT and productivity: conclusions from the empirical literature. Information Economics and Policy, 25(3), 109-125.

https://doi.org/10.1016/j.infoecopol.2012.12.002

Chandan, K., \& Nalin, B. (2018). Indo-EU Agricultural Trade: Trade Restrictions and SPS Measures. Obuda University e-Bulletin, 8(1), 13-23.

Chimobi, O. P. (2010). Inflation and economic growth in Nigeria. Journal of sustainable Development, 3(2), 159. https://doi.org/10.5539/jsd.v3n2p159

Crespo-Cuaresma, J., Ritzberger-Grünwald, D., \& Silgoner, M. A. (2008). Growth, convergence and EU membership. Applied Economics, 40(5), 643-656.

https://doi.org/10.1080/00036840600749524

Devereux, M. P., Griffith, R., \& Klemm, A. (2002). Can international tax competition explain corporate income tax reforms. mimeo.

Dewan, S., \& Kraemer, K. L. (2000). Information technology and productivity: evidence from country-level data. Management science, 46(4), 548-562.

https://doi.org/10.1287/mnsc.46.4.548.12057

Dimelis, S. P., \& Papaioannou, S. K. (2010). FDI and ICT effects on productivity growth: A comparative analysis of developing and developed countries. The European Journal of Development Research, 22(1), 79-96. https://doi.org/10.1057/ejdr.2009.45

Dowrick, S., \& Golley, J. (2004). Trade openness and growth: who benefits?. Oxford review of economic policy, 20(1), 38-56. https://doi.org/10.1093/oxrep/grh003

Ehigiamusoe, K. U., \& Lean, H. H. (2019). Do economic and financial integration stimulate economic growth? A critical survey. Economics, 13(1).

https://doi.org/10.5018/economics-ejournal.ja.2019-4

European Commission. (2015). A Digital Single Market Strategy for Europe. [Online] Available: http://eur-lex.europa.eu/legalcontent/EN/TXT/?qid=1447773803386\&uri=CELEX \%3A52015DC0192.com

Fetahi-Vehapi, M., Sadiku, L., \& Petkovski, M. (2015). Empirical analysis of the effects of 
trade openness on economic growth: An evidence for South East European countries. Procedia Economics and Finance, 19, 17-26.

https://doi.org/10.1016/S2212-5671(15)00004-0

Field, A. J. (2006). Technological change and US productivity growth in the interwar years. The Journal of Economic History, 66(1), 203-236.

https://doi.org/10.1017/S0022050706000088

Greenaway, D., Morgan, W., \& Wright, P. (2002). Trade liberalisation and growth in developing countries. Journal of development economics, 67(1), 229-244.

https://doi.org/10.1016/S0304-3878(01)00185-7

Gruber, H., Hätönen, J., \& Koutroumpis, P. (2014). Broadband access in the EU: An assessment of future economic benefits. Telecommunications Policy, 38(11), 1046-1058.

https://doi.org/10.1016/j.telpol.2014.06.007

Grubert, H., \& Mutti, J. (2000). Do taxes influence where US corporations invest?. National Tax Journal, 53(4), 825-839. https://doi.org/10.17310/ntj.2000.4.02

Hansen, L. P. (1982). Large sample properties of generalized method of moments estimators. Econometrica: Journal of the econometric society, 1029-1054.

https://doi.org/10.2307/1912775

Hanushek, E. A., \& Kimko, D. D. (2000). Schooling, labor-force quality, and the growth of nations. American economic review, 90(5), 1184-1208. https://doi.org/10.1257/aer.90.5.1184

Harrison, A. (1996). Openness and growth: A time-series, cross-country analysis for developing countries. Journal of development Economics, 48(2), 419-447.

https://doi.org/10.1016/0304-3878(95)00042-9

Henrekson, M., Torstensson, J., \& Torstensson, R. (1997). Growth effects of European integration. European Economic Review, 41(8), 1537-1557.

https://doi.org/10.1016/S0014-2921(97)00063-9

Hossine Sharif, S. (2016). The Role of Telecommunication over the Economic Development of Bangladesh. University Library of Munich, Germany. https://doi.org/10.2139/ssrn.2812019

Ishida, H. (2015). The effect of ICT development on economic growth and energy consumption in Japan. Telematics and Informatics, 32(1), 79-88.

https://doi.org/10.1016/j.tele.2014.04.003

Italianer, A. (1994). Whither the gains from European economic integration?. Revue économique, 689-702. https://doi.org/10.2307/3502355

Iyidoğan, P. V., Dalgiç, B., \& Akbulut, H. (2017). Is there a non-linear relationship between trade and growth? A panel threshold analysis for Central and Eastern European countries. Acta Oeconomica, 67(1), 117-136. https://doi.org/10.1556/032.2017.67.1.7

Jalava, J., \& Pohjola, M. (2007). ICT as a source of output and productivity growth in Finland. Telecommunications Policy, 31(8-9), 463-472. 
https://doi.org/10.1016/j.telpol.2007.05.011

Kien, N. T. (2009). Gravity model by panel data approach: an empirical application with implications for the ASEAN free trade area. ASEAN Economic Bulletin, 266-277. https://doi.org/10.1355/AE26-3C

Ehigiamusoe, K. U., \& Lean, H. H. (2019). Do economic and financial integration stimulate economic growth? A critical survey. Economics, 13(1).

https://doi.org/10.5018/economics-ejournal.ja.2019-4

Kraemer, K. L., \& Dedrick, J. (2001). Information technology and productivity: results and policy implications of cross-country studies. In M. Pohjola (Ed.), Information technology, productivity and economic growth (pp. 257-279). Oxford: Oxford Universtity Press. https://doi.org/10.1093/acprof:oso/9780199243983.003.0012

Kumar, N., \& Kumar, R. R. (2020). Relationship between ICT and international tourism demand: A study of major tourist destinations. Tourism Economics, 26(6), 908-925. https://doi.org/10.1177/1354816619858004

Kuznets, S. (1978). Technological innovations and economic growth. In Technological Innovation: A Critical Review of Current Knowledge. San Francisco: San Francisco Press. pp. 476-541.

Landau, D. (1995). The contribution of the European common market to the growth of its member countries: An empirical test. Review of World Economics, 131(4), 774-782. https://doi.org/10.1007/BF02707941

Latif, Z., Latif, S., Ximei, L., Pathan, Z. H., Salam, S., \& Jianqiu, Z. (2018). The dynamics of ICT, foreign direct investment, globalization and economic growth: Panel estimation robust to heterogeneity and cross-sectional dependence. Telematics and Informatics, 35(2), 318-328. https://doi.org/10.1016/j.tele.2017.12.006

Lind, D. A., Marchal, W. G. \& Wathen, S. A. (2012). Statistical Techniques in Business \& Economics. New York: McGraw-Hill Irwin.

Loretz, S. (2007). Determinants of bilateral effective tax rates: Empirical evidence from OECD countries. Fiscal Studies, 28(2), 227-249.

https://doi.org/10.1111/j.1475-5890.2007.00055.x

Maiti, D., \& Awasthi, A. (2020). ICT exposure and the level of wellbeing and progress: A cross country analysis. Social Indicators Research, 147(1), 311-343.

https://doi.org/10.1007/s11205-019-02153-5

Makki, S. S., \& Somwaru, A. (2004). Impact of foreign direct investment and trade on economic growth: Evidence from developing countries. American journal of agricultural economics, 86(3), 795-801. https://doi.org/10.1111/j.0002-9092.2004.00627.x

McConnell, C. R., Brue, S. L., Flynn, S. M., \& Grant, R. R. (2013). Macroeconomics: Brief Edition. McGraw-Hill/Irwin. 
Murphy, R. H., \& O’Reilly, C. (2019). Applying panel vector autoregression to institutions, human capital, and output. Empirical Economics, 57(5), 1633-1652.

https://doi.org/10.1007/s00181-018-1562-0

Ndambiri, H. K., Ritho, C., Ng’ang'a, S. I., Kubowon, P. C., Mairura, F. C., Nyangweso, P. M., \& Cherotwo, F. H. (2012). Determinants of economic growth in Sub-Saharan Africa: A panel data approach. Management, 2(2), 18-24.

Negreiro, M. (2015). European Parliamentary Research Service-EPRS. [Online] Available: http://www.europarl.europa.eu/RegData/etudes/BRIE/2015/573884/EPRS_BRI(2015)573884 _EN.pdf

Paparas, D., Richter, C., \& Paparas, A. (2015). Fiscal policy and economic growth, empirical evidence in European Union. Turkish Economic Review, 2(4), 239-268.

Putranti, I. R. (2016). EU Regulations on Illegal, Unreported, and Unregulated Fishing (IUU): Implications for ASEAN Community Fisheries Legal Frameworks. Russian Journal of Comparative Law, 3, 91-105.

Raheem, I. D., Tiwari, A. K., \& Balsalobre-Lorente, D. (2020). The role of ICT and financial development in CO 2 emissions and economic growth. Environmental Science and Pollution Research, 27(2), 1912-1922. https://doi.org/10.1007/s11356-019-06590-0

Rassekh, F. (2007). Is international trade more beneficial to lower income economies? An empirical inquiry. Review of Development Economics, 11(1), 159-169.

https://doi.org/10.1111/j.1467-9361.2006.00357.x

Roller, L. H., \& Waverman, L. (2001). Telecommunications infrastructure and economic development: A simultaneous approach. American economic review, 91(4), 909-923. https://doi.org/10.1257/aer.91.4.909

Saaed, A. A. (2007). Inflation and economic growth in Kuwait: 1985-2005-Evidence from co-integration and error correction model. Applied Econometrics and International Development, $7(1)$.

Seifallah, S., \& Mohamed, G. (2013). Financial development, ICT diffusion and economic growth: Lessons from MENA region. Telecommunications Policy, 37(2013), 252-261. https://doi.org/10.1016/j.telpol.2012.12.004

Sharma, S. C., \& Chua, S. Y. (2000). ASEAN: economic integration and intra-regional trade. Applied Economics Letters, 7(3), 165-169. https://doi.org/10.1080/135048500351726

Timmer, M. P., O Mahony, M., \& Van Ark, B. (2007). EU KLEMS growth and productivity accounts: an overview. International Productivity Monitor, 14, 71.

https://doi.org/10.1177/0027950107080390

Vanhoudt, P. (1999). Did the European unification induce economic growth? In search of scale effects and persistent changes. Weltwirtschaftliches Archive, 135(2), 193-220. https://doi.org/10.1007/BF02707252 
Vatcheva, K. P., Lee, M., McCormick, J. B., \& Rahbar, M. H. (2016). Multicollinearity in regression analyses conducted in epidemiologic studies. Epidemiology (Sunnyvale, Calif.), 6(2), 227-235. https://doi.org/10.4172/2161-1165.1000227

Venturini, F. (2009). The long-run impact of ICT. Empirical Economics, 37(3), 497-515. https://doi.org/10.1007/s00181-008-0243-9

Vijselaar, F., \& Albers, R. (2004). New technologies and productivity growth in the euro area. Empirical Economics, 29(3), 621-646. https://doi.org/10.1007/s00181-004-0202-z

Vogiatzoglou, K., \& Nguyen, P. N. T. (2016). Economic openness and economic growth: A cointegration analysis for ASEAN-5 countries. The European Journal of Applied Economics, 13(2), 10-20. https://doi.org/10.5937/ejae13-11311

Vu, Y. H., Nguyen, N. T., Nguyen, T. T., \& Pham, A. T. (2019, January). The threshold effect of government's external debt on economic growth in emerging countries. In International Econometric Conference of Vietnam (pp. 440-451). Springer, Cham.

https://doi.org/10.1007/978-3-030-04200-4_32

World Bank. (2019). World Development Indicators. [Online] Available:

http://databank.worldbank.org/data/ download/WDI_excel.zip

Yanikkaya, H. (2003). Trade openness and economic growth: a cross-country empirical investigation. Journal of Development economics, 72(1), 57-89.

https://doi.org/10.1016/S0304-3878(03)00068-3

Wyatt, S., Henwood, F., Hart, A., \& Smith, J. (2005). The digital divide, health information and everyday life. New Media \& Society, 7(2), 199-218.

https://doi.org/10.1177/1461444805050747

Tumwebaze, H. K., \& Ijjo, A. T. (2015). Regional economic integration and economic growth in the COMESA region, 1980-2010. African Development Review, 27(1), 67-77.

https://doi.org/10.1111/1467-8268.12123

\section{Copyright Disclaimer}

Copyright for this article is retained by the author(s), with first publication rights granted to the journal.

This is an open-access article distributed under the terms and conditions of the Creative Commons Attribution license (http://creativecommons.org/licenses/by/4.0/). 